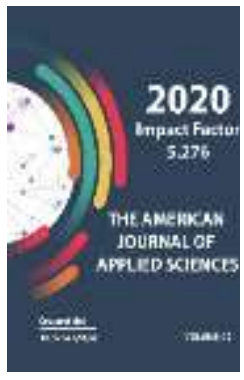

Journal Website: http://usajournalshub.c om/index,php/tajas

Copyright: Original content from this work may be used under the terms of the creative commons attributes 4.0 licence.

\section{Development Of Ecoturism In Aydar-Arnasay Lakes System And Its Surroundings}

\author{
Mirkomil Gudalov \\ Candidate Of Geographical Science, Associate Professor JSPI Department Of Geography And \\ Fundamentals Of Economics, Uzbekistan
}

Dilfuza Imamova

Associate Professor, Candidate Of Biology Science JSPI Department Of Biology Teaching Methods, Uzbekistan

\title{
ABSTRACT
}

The prospects of development of ecotourism with consideration of natural geographical features of Aydar-Arnasay swamp were analyzed.

\section{KEYWORDS}

Aydar-Arnasay swamp, viator, ecotourism, natural laboratory, touristic zone, botel, flotel.

\section{INTRODUCTION}

The Aydar-Arnasay basin is located between the largest mountain ranges and deserts of the natural geographical region of Central Asia, ie in the intermediate zone of the mountainous and foothill areas of West Turkestan, which is connected with the Kyzylkum desert. The depression also has an arched appearance due to its location in a tectonic fault [1. Alibekov L].
It is no exaggeration to say that the AydarArnasay basin is a "natural laboratory" area, which is rapidly developing under the interaction of mountain, hill, desert regions and a large body of water. The development of natural geographical processes in the AydarArnasay basin is influenced by anthropogenic factors in parallel with natural factors. The study, analysis and forecasting of the future 
development of the Aydar-Arnasay basin and its changes, which are the product of various influences and factors, are of great scientific and practical importance.

\section{THE MAIN PART}

Although the area of the Aydar-Arnasay basin (about 5 thousand $\mathrm{km} 2$ ) is small, it differs from other basins by its biological diversity and fascinating nature. The central part of the Aydar-Arnasay basin is occupied by the AydarArnasay lake system. The Aydar-Arnasay lake system has an area of $3,791 \mathrm{~km} 2$, a volume of $44.19 \mathrm{~km} 3$, a length of $350 \mathrm{~km}$ from west to east, and a width of $2 \mathrm{~km}$ to $40 \mathrm{~km}$ from north to south. The increase in the size of the lake, in turn, is the basis for microclimate change, the emergence of new flora and fauna, the expansion of coastal zones and, in turn, the development of tourism [2. Gudalov M].

In order to further increase the efficiency and rational use of biological resources of the Aydar-Arnasay lake system and the development of tourism, in recent years the Cabinet of Ministers of the Republic of Uzbekistan has adopted 2 important decisions (№. 124 of 07.03.2017 and №. 347 of 22.04.2019). In 2017, practical work began on the establishment of "tourist zones" on the shores of the Aydar-Arnasay lake system.

Taking into account the number of tourists visiting the Aydar-Arnasay lake system and the surrounding ecotourism area is one of the important stages in the development of tourism. Most foreign tourists visiting the ecotourism zone of the Aydar-Arnasay lake system first come to Jizzakh and then visit the lakes. When going from Jizzakh to the AydarArnasay lake system, it is necessary to choose a route, taking into account the harmony of natural landscapes and road infrastructure [3. Gudalov M].

We recommend the following route, which includes a distance of $93 \mathrm{~km}$ for tourists traveling from Jizzakh to the Aydar-Arnasay lake system. Along this route you can see limestone mining in Pistalikent (Temiryazov), steep cliffs in the Kli valley, views of Pistalitog, lakes and healing muds of Tuzkon, Aydar and Arnasay, views of tugai and desert, Mirzachul mineral waters and medical facilities.

\section{RESULTS AND DISCUSSIONS}

Much attention is paid to improving the infrastructure around the Aydar-Arnasay lake system, including the construction and repair of roads, the construction of hotels and campsites, as well as the provision of services. When building hotels on the shores of the lake, it is necessary to take into account the natural geographical features of the place. When building hotels, it is necessary to find a "comfortable space" between the lake and the hotel. To do this, it is important to find a "convenient intermediate" zone, where the groundwater level does not rise, and at night, when the wind blows from the lake, the mosquitoes can not reach the lake.

In order to observe the nature of the AydarArnasay lake system and the surrounding ecotourism area and to hunt in the designated area, Arab tourists regularly come to rest twice a year (in spring and autumn). Arab tourists are interested in the area, the harmony of lakes and deserts and the richness of the bird world, as well as the constant movement of birds flying to the hot regions in spring and autumn through the Aydar-Arnasay lake system and hunting some permitted birds. The most notable aspect of Arab tourists 'hunting is that they mostly use falcons brought with them during the hunting process. Hunting with falcons does no more harm to nature than hunting with hunting rifles [4. Gudalov M].

In the early 2000s, crowned falcons brought from Saudi Arabia were released under special markings on the shores of the Aydar-Arnasay lake system, adjacent to the Kyzylkum Desert. According to ornithologists, the number of crowned falcons increased to 25-30 in 2014 [5. 
Gudalov M]. It can be assumed that the number of crowned falcons has now increased even more. 13 species of birds living here are included in the International Red Book, 24 species in Uzbekistan are included in the Red Book.

Another aspect that attracts tourists to the Aydar-Arnasay lake system is fishing. The Aydar-Arnasay lake system is home to 22 species of fish. Of these, 13 species are native. In the 1960s, various fish species were imported and bred from the northern watersheds of the former Soviet Union in order to develop fisheries in Uzbekistan, clear canals and ditches of various weeds, and reduce malaria-carrying mosquitoes. For example, white amur, gambuziya, dongpeshona and others. 7 species of fish entered the AydarArnasay lake system through the Syrdarya River. In total, 14 species of fish are of great hunting importance. These include squirrels, squirrels, white squirrels, corpses, pikeperch, squirrels, squirrels, squid, squirrels, and others. Due to the decline, Turkestan carp is included in the Red Data Book of Uzbekistan [6. Sharipov Sh].

The Aydar-Arnasay lake system catches more than 500,000 tons of fish a year. Fishing with the help of small nets is a unique obstacle to the development of the industry. Fishing with hooks will do very little damage to the fishing industry, which tends to catch with nets. For this reason, it is necessary to create special areas on the shores of the Aydar-Arnasay lake system and start fishing only with hooks. This, in turn, would lead to an increase in the flow of interesting vacationers fishing on the shores of the lake.

Most of the tourists who come to the AydarArnasay lake system come for swimming and fishing. Lake Tuzkon is the best place for swimming and recreation. Tuzkon Lake water is rich in various mineral elements and has a natural healing effect if there are various rashes on the body of a bathed person. In addition, the sandy shores of Lake Tuzkan serve as a natural beach [7. Sharipov Sh].

In order to provide a high level of service to tourists in the Aydar-Arnasay lake system, it is important to consider and implement ideas for the establishment of floating botel and flotel hotels. Tourists who come to the lake give a unique exotic pleasure when they relax in the floating botel or flotel hotels. Here we will tell you about botel and flotel hotels. The Botel is a small water hotel. A ship with equipped amenities. Flotel is a sailing hotel ship. The huge hotel on the water will be specially equipped. In addition to comfortable numbers, there is a convenience for a good rest, the use of a temporary office, operative means of communication: telephone, copier, fax and other services.

\section{CONCLUSION}

In addition to the types of tourism discussed above, there are opportunities to develop several other types of tourism. These include:

- Establishment of various water sports and competitions in the Aydar-Arnasay lake system;

- International cross-country racing in the sandy deserts on the north-eastern shores of the Aydar-Arnasay lake system;

From the camels, which are common in the deserts around the Aydar-Arnasay lake system, it is also necessary to arrange for tourists to travel and be treated with camel milk.

In conclusion, it is worth noting the comprehensive development of ecotourism, taking into account the Aydar-Arnasay lake system and the surrounding natural environment.

\section{REFERENCES}

1. Alibekov L, Alibekova S, Hazarov I, Gudalov M. About some regularities of degradation geosystems in Central Asia. Tatranka 
Javorina, Slovakia, 2012, Vol 21, № -1, 42-44

$r$

2. Gudalov M. Foundation of Aydar-Arnasay lakes system and their effects on the environmental landscape. Nature and Science.Volume 17, Number 11 November 25, 2019 USA New York.

3. Gudalov M., Zikirov B. Metnods of studying the landscapes around the Aydar-Arnasay lake system. International engineering journal for research \& development. Vol - 5, Issue - 7, 2020 India.

4. Gudalov M., Zikirov B., Imamova D. Predicting changes in landscares around the Aydar-Arnasay lake system. Accerted in the journal The American of Engineering and Technology. Volume - 02, Issue - 10, October 2020.

5. Gudalov M., Gozieva M. Ways to develor modern ecoturism in the Zamin basin. International engineering journal for research \& development. Vol - 5, Issue - 7, 2020 India.

6. Sharipov Sh, Gudalov M, Shomurodova Sh. Geolologic situation in the Aydar-Arnasay colony and its atropny. Journal of Critical Reviews. Volume 7, Issue 3, 2020 Malaysia Kuala Lumpur.

7. Mukhamajanovich, S. S., Gayratovna, S. S., \& Ravshanovich, G. M. (2020). The use of the mountain kars in the tourism sphere in cort and recreation zone of ChimganCharvak. Journal of Critical Reviews, 7(3), 475-481.

8. Gudalov, M. R. (2011). Analysis of natural and anthropogenic processes in the Aydar hollow. Izvestiya of the Uzbekistan Geographical Society.

9. Mirkomil, G., \& Matluba, G. (2020). WAYS TO DEVELOP MODERN ECOTOURISM IN THE ZAAMIN BASIN. International Engineering Journal For Research \& Development, 5(7), 5-5.

10. Mirkomil, G., Bakhtiyor, Z., \& Dilfuza, I. (2020). Predicting Changes In Landscapes Around The Aydar-Arnasay Lake System.
The American Journal of Engineering and Technology, 2(10), 6-12.

11. Mirkomil, G., \& Bakhtiyor, Z. (2020). METHODS OF STUDYING THE LANDSCAPES AROUND THE AYDARARNASAY LAKE SYSTEM. International Engineering Journal For Research \& Development, 5(7), 5-5.

12. Baymetov, B. B., \& Muratov, K. K. (2020). Self Sketches as a Tool in the Professional Training of a Future Artist-Teacher. Solid State Technology, 224-231.

13. Baymetov, B. B. (2020). Art Of Modern Uzbekistan: The History of Its Development During The Years Of Independence. The American Journal of Social Science and Education Innovations, 2(10), 125-132.

14. Gudalov M. R.( 2012). About some regularities of geosystems degradation in Central Asia. About some regularities of geosystems degradation in Central Asia. 